\title{
The neuroprotective attribution of Ocimum basilicum: a review on the prevention and management of neurodegenerative disorders
}

Mohamed Ali Seyed ${ }^{1 *}$ (D), Siddiqua Ayesha ${ }^{2}$, Norazrina Azmi ${ }^{3}$, Fahad Mohamed Al-Rabae ${ }^{1}$, Adel Ibrahim Al-Alawy ${ }^{1}$, Othman Rashed Al-Zahrani ${ }^{4}$ and Yousef Hawsawi ${ }^{5}$

\begin{abstract}
Background: Bioactive principles from various natural resources including medicinal herbs have always played a crucial role in healthcare settings and increasingly became key players in drug discovery and development for many biopharmaceutical applications. Additionally, natural products (NPs) have immense arrangement of distinctive chemical structures with diverse functional groups that motivated numerous investigators including synthetic chemists to discover new therapeutic entities. Numerous pre-clinical investigations involving the animal models have evident the usefulness of these NPs against various human diseases including neurodegenerative disorders (NDs).

Main text: Ocimum basilicum Linn (O. basilicum L.), also known as sweet basil, is well practiced in traditional healthcare systems and has been used to treat various human illnesses, which include malaria, skin disease, diarrhea, bronchitis, dysentery, arthritis, eye diseases, and insect bites and emphasize the significance of the ethnobotanical approach as a potential source of novel drug leads With the growing interest in advanced techniques, herbal medicine and medicinal plants explorations are still considered to be a novel resource for new pharmacotherapeutic discovery and development. O. basilicum $L$ and its bioactive principles including apigenin, eugenol, myretenal, $\beta$-sitosterol, luteolin, rosmarinic acid, carnosic acid, essential oil (EO)-rich phenolic compounds, and others like anthocyanins and flavones could be of therapeutic values in NDs by exhibiting their neuroprotective efficacy on various signaling pathways. The present comprehensive review collected various related information using the following searching engines such as PubMed, Science Direct, Google Scholar, etc. and focused mainly the English written documents. The search period comprised of last two decades until present.

Conclusion: Although these efficacious plant genera of prime importance and has potential medical and socioeconomic importance, yet the pivotal evidence for its neuroprotective potential in novel clinical trials remains lacking. However, with the available wealth of obtainable literature on this medicinal plant, which supports this review and concludes that $O$. basilicum $L$ may function as a promising therapeutics for the treatment of NDs.
\end{abstract}

Keywords: Ocimum basilicum, Neuro-protection, Prevention, Phytoconstituents, Neurodegeneration, NPs

\footnotetext{
* Correspondence: sdmdaliali@gmail.com

'Department of Biochemistry, Faculty of Science, University of Tabuk, Tabuk

71491, Kingdom of Saudi Arabia

Full list of author information is available at the end of the article
}

\section{Springer Open}

(c) The Author(s). 2021 Open Access This article is licensed under a Creative Commons Attribution 4.0 International License, which permits use, sharing, adaptation, distribution and reproduction in any medium or format, as long as you give appropriate credit to the original author(s) and the source, provide a link to the Creative Commons licence, and indicate if changes were made. The images or other third party material in this article are included in the article's Creative Commons licence, unless indicated otherwise in a credit line to the material. If material is not included in the article's Creative Commons licence and your intended use is not permitted by statutory regulation or exceeds the permitted use, you will need to obtain permission directly from the copyright holder. To view a copy of this licence, visit http://creativecommons.org/licenses/by/4.0/. 


\section{Background}

Neuronal atrophy often described as neurodegeneration caused by degradation and subsequent loss of functional neurons which is predominantly witnessed among elderly population as wide spectrum chronic neurodegenerative diseases (NDs) of the central nervous system (CNS) [1-3]. The deficiency of quality treatment results to enormous socio-economic burdens [4]. Normally, NDs are described as characteristic loss of loss of neurons and their functions in numerous regions of the CNS, which include Parkinson's disease (PD), in which loss of dopaminergic nigrostriatal neurons are characteristic features, whereas in Huntington's disease (HD), a loss of medium-sized striatal spiny neurons and diffuse cerebral atrophy was evident in Alzheimer's disease (AD). Besides the above, primary dystonia or essential tremor and a few other motor defects/impairments are also denoted as NDs [5, 6].

Over the years, NDs share few clinical characteristics like the relentless progression of the disease even for decades [7]. Beyond the known well-characterized pathogenic causative mechanisms of individual illnesses, neurodegeneration is considered as the gradual loss of functional properties of neurons by the various chains of events leading to cell death, which represents the key point of this group of diseases [8]. Although numerous immense strive have been made to recognize the pathophysiology of NDs and their related technological advancements to address the issues pertaining to NDs, but little only achieved in developing effective therapies [9]. Moreover, the current therapies are adequate to alleviate symptoms only, not to stop the progress of the disease.

\section{Contributing factors for the formation of neuro- degeneration}

Though pathophysiology of NDs along with the available treatment interventions for NDs, it is still necessary to brief the causative factors like hereditary, environmental, and oxidative stress and various other factors, etc., which are involved in the formation of NDs, which will shine more light on the investigators, who are involved in the discovery of new therapeutic options.

\section{Role of genetics and hereditary}

In the past few decades, various discoveries made our understanding of the etiology, causative genes, and mechanisms involved in the formation of hereditary NDs and promoted to identify the development of newer therapies. For example, in ADs, there are penetrant mutations in three genes like amyloid protein precursor (APP), PSEN 1, and PSEN 2, which are accountable for the onset of early familial AD. Studies have identified 8causative genes (e.g., UCH-L1, a-synuclein, PINK1, parkin, DJ-1, OMI/HTRA2, LRRK2, and ATP13A2) and 4 additional loci of linkage across the genome (PARK3, 10, $11,12)$ responsible for $\mathrm{PD}$; however, still pending characterization and/or replication exists $[10,11]$.

\section{Role of oxidative stress}

It is well established that oxidative stress is the major cause of neural atrophy; however, its associated consequence remains elusive. However, in general, neuronal degradation caused by mitochondrial damage and oxidative stress results in DNA damage [12]. Mitochondrial and endoplasmic reticulum enzymes like P450 are some of the endogenous sources of reactive oxygen species (ROS) [13] together with oxidative radicals from cellular catabolism are responsible for the development of aging related degenerative disorders [14]. The natural antioxidant defence system exists in the human body comprised of glutathione, catalase, and superoxide dismutase (SOD) neutralizes these radical oxidants [15-17]. Besides, the continued accumulation of radical species in an impaired oxidant defence environment initiates neuronal cell death together with the involvement of proapoptotic Bcl-2 family members [18]. Human brains are highly susceptible to oxidative strains [19]. The brain has a high oxygen demand and contains high levels of polyunsaturated FAs mostly in the cell membranes act as substrates in the lipid peroxidation process [20]. The huge presence of oxidized polyunsaturated fatty acids (PUFAs) like arachidonic linoleic acid [19, 21] mostly worsens NDs symptoms [22].

\section{Role of environmental factors}

Besides, various environmental factors also contribute to the progression of NDs. Prolonged exposure of manganese and few toxic solvents are associated with mitochondrial dysfunction and accumulation of $\alpha$-synuclein in PD [23]. In line with this, mercury and Lead increase the accumulation of tau protein and $A \beta$ plaques, both of these involved in the formation of AD. Though these metal elements are essential for many biological reactions, interruption in their homeostasis results in free radical production. Normally, intracellular iron is bound by ferritin as an insoluble ferrihydrite form. 6hydroxydopamine (6-OHDA), a well-known neurotoxin reduces core iron to liberate ferrous form. The reduced ferrous form stimulates lipid peroxidation; however, this process inhibited by an iron chelator deferoxamine. Studies have shown occupational exposure to pesticides cause neuronal impairment in aged people, thereby highlighting the toxic role of pesticides [24]; however, the consumption of sufficient amount of fruits, vegetables, and fish oil rich in omega- 3 reduce the risk of dementia and $\mathrm{AD}$ with the involvement of apolipoprotein E (APOE-ع4) [25]. 


\section{Role of protein misfolding and aggregation}

Proteins are complex biomolecules, which are essential for various fundamental cellular processes. Long stretched amino acid chains and polypeptide chains folded as 3D structures to attain its functional state [26], which is required for the normal functional of the specific protein [27]. The truncated or misfolded proteins may lead to clumps or aggregation formation mainly in the hydrophobic regions [28]. Since AD and PD are classical example of protein-misfolding of NDs are caused by the accumulation of abnormal misfolded proteins, subsequent deposition of the aggregated plaques, and associated with various cellular dysfunctions [29], which are normally protected by molecular chaperons [30]. Firstly, the protein chaperons bind with unfolded proteins and/or newly synthesized proteins through ATP hydrolysis, which then contribute to the completion of mature protein confirmation process by recruiting ubiquitin ligases to target misfolded proteins and subsequently cleared by proteolytic process [31, 32].

Upon injury, the following causative factors like ions imbalance, oxidative stress, mitochondria dysfunction, apoptosis, cytotoxicity, necrosis, inflammation, and altered blood-brain permeability contribute to morphological and pathological modifications; most of the time, this aggravate medical conditions. Besides the above, the current availability of few well-demonstrated synthetics as well as semi-synthetic therapeutics for the management of NDs; but most of them exerted severe adverse effects [33]. The above-listed contributing factors suggest exploring other possibilities for the employment of novel screening and various other alternative neuroprotection approaches [34].

\section{Main text}

Natural medicinal plants have been widely used by traditional medical practitioners to treat various human illnesses [35-38]. Since research investigations on the development of new drugs are time-consuming and require a large capital investment, the focus is now being shifted to treatment strategies using herbal medicine obtained from various resources mainly from medicinal plants, which are plenty available and cost effective [3941]. With the growing interest in advanced techniques, herbal medicine research, and medicinal plant, explorations are still considered to be a novel resource for new pharmacotherapeutic discovery and development [42]. However, isolation and development of clinically important drug leads from plants face enormous challenges [43] even after adopting high-throughput drug screening assays, because it is required to make extract compound libraries to screen biological activity [44, 45]. Despite having various challenges, NPs from herbal plants remain an indispensable constituent in the search for new drugs $[40,46,47]$.

The bioactive principles or secondary metabolites pool symbolizes a constant main source for drug discovery and development $[33,48]$. Hence, a detailed discussion on plant-derived important bioactive principles will be vital for developing new and novel therapeutics as they may amplify each other's activity with devoid of harmful side effects. Hence, traditional herbal research emphasizes aspects that warrant further investigation to establish its activity and utility for various diseases including neuro-protection and treatment. Although many herbal medicines are in place for the treatment of various NDs [49-53], still it is yet to be known how these compounds cure or alleviate many symptoms of NDs [54]. Moreover, these bioactive compounds, cellular targets, and their molecular mechanisms require detailed insight.

Neuro-protection means the mechanisms and approaches employed to protect the brain against various injuries of both acute and chronic NDs such as Parkinson's, Epilepsy, Dementia, Alzheimer's, etc. [55]. Traditional herbal therapeutics as well as nutraceuticals signify their vital importance in the prevention of NDs rather than the treatment $[56,57]$. Although pathogenic mechanisms of numerous neurological disorders are not completely known, however, several results have highlighted key features of NDs based on the cues obtained from various neural disorder models as they mimicked most important characteristic features like mitochondrial dysfunction, oxidative load, neuroinflammation, etc. $[58,59]$. Various investigative models have developed as an important tool to study neurotoxicity and symptomatic treatments. These methods have used as novel therapeutic strategies to assess these plant-derived compounds efficacy and their adverse effects [60].

Besides the above, many studies have described the neuro-protective properties of NPs by modulating numerous signaling cascades through direct effects on various cellular targets like kinases, numerous proteins including regulatory receptors $[61,62]$. In addition, various results have also demonstrated other important pharmacological actions of NPs like chromatin remodeling and epigenetic modifications [63]. This broad spectrum of pharmacological properties has signified NPs as suitable therapeutic agents for the treatment of NDs/neurological disorders $[64,65]$.

\section{Prospective role of medicinal plants in NDs}

In recent times, the quest for novel therapeutics and their applications in the treatment of NDs more notably $\mathrm{PD}, \mathrm{HD}$, and $\mathrm{AD}$ gained enormous attention among investigators. Parkinson's disease incidence among aging population worldwide is increasing and considered as 
second highest leading hetero-degenerative disease, dopaminergic neuronal degeneration in the substantia nigra of the basal ganglia region. Its hallmark features bring the following outcomes like rigid nature, developing balance loss together with other symptoms [66]. Protein deposits, also called Lewy bodies or cytoplasmic inclusions, are considered as one of the pathological characteristic feature, which are formed by the binding of $\alpha$-synuclein to ubiquitin [67] causing dopaminergic neuronal degeneration [68]. Besides, PD has also been associated with several biochemical parameters, which include depletion of intracellular thiols, increased nigral iron content, and deficiency of mitochondrial complex I [69].

L-DOPA, a dopamine precursor (1-3, 4dihydroxyphenylalanine), is the only therapeutic available to decreases the motor symptoms of PD, but it exerts side effects like dyskinesias [70]. To overcome the side effects caused by current medication and synthetic products, investigators have shifted their attention to various NPs. In this regard, several herbal plants/NPs including ginger, turmeric, pepper, and cloves with neuroprotective effects against PD have been reported [71, 72]. Besides, the consumption of green tea [73] and securinine obtained from Securinega suffruticosa are beneficial against age-related neurological problems by inhibiting NF- $\mathrm{kB}$, mitogen-activated protein kinase (MAPK), and interferon gamma (IFN- $\gamma$ ) activity expression and reducing the activity of iNOS and NO level, thereby delay the onset of PD [74]. Huntington's disease (HD) or Huntington's chorea is inherent autosomal dominant NDs [75-77]. HD is characterized by personality changes, emotional imbalance, memory loss, the diminished capability to think clearly, weight loss, etc. [78-81]. Many beneficial therapeutic effects are attributed to medicinal plants to cure NDs, which include antioxidant, anti-apoptotic, and anti-inflammatory activities and neuronal function modulation [82, 83]. A growing number of medicinal plants are in use as a therapeutic for NDs including HD; they are Centella asiatica, Gastrodia elata, Panax ginseng, Withania somnifera, Cannabis sativa, Ginkgo biloba, Bacopa monnieri (BM), etc.

The following neuro-protective compounds, which include kaempferol, naringin, resveratrol, ginsenosides, curcumin, S-allylcysteine, and EGCG extracted from various herbal plants have employed to treat HD [50]. Among them, BM has proven its efficacy for HD as a potentially powerful antioxidant against oxidative damage instigated by neuro-toxicants and relieves stressmediated neuronal impairment [84]. Besides, a few other plant-derived compounds like sesamol isolated from sesame oil, celastrol (triterpenoid quinine methide), and lycopene from tomatoes and tomato-based products used as antioxidants to treat HD [85] [86-89]. To support this, flavonoids also inhibit nitric oxide synthase (NOS) and hence delay HD progression [90-92]. Curcumin, a natural compound in turmeric, has inhibited motor defects and increased succinic acid dehydrogenase $(\mathrm{SDH})$ function in 3-nitropropionic acid (3-NP)-induced neuronal disorders observed akin with HD patients [93, 94]. In addition, Resveratrol reversed 3-NP induced cognitive as well as motor defects $[94,95]$.

On the other hand, Alzheimer's disorder is considered as one of the severe and age-related chronic ND with the expectation of affecting nearly 107 million people by the year 2050 [96, 97]. It has the following characteristic features like impaired memory and cognitive function. The generation of amyloid- $\beta$ (A $\beta$ ) fibrils is the hallmark pathogenesis of $\mathrm{AD}$, which contains $\beta$-amyloid peptides. Though the precise mechanism of amyloid plaques generation is not clear, however, there are some plausible explanations given that $A \beta$ normally formed and accumulated within the extracellular matrix (ECM) [98]. Few studies have also reported the therapeutic potential of nutraceuticals against $A \beta$ plaques formation [49, 99]. Furthermore, numerous investigations have demonstrated the role of oxidative stress in AD patients' brains [100]. The antioxidant potential of some phytoconstituents like anthocyanins, carotenoids, etc. from Arbutus unedo plant has shown their greater antioxidant effects [101, 102]. Anthocyanins from Vaccinium angustifolium and resveratrol from Vitis vinifera have also demonstrated their alleviation action against oxidative stressinduced inflammation via stimulation of sirtuin-1 activity and decrease nuclear factor kappa B (NF-kB) expression [103].

Even though a huge number of evidence suggest that herbal plants offer a therapy for NDs, yet plenty of unidentified and unknown reservoir plants line up for exploration and proper investigation. Based on the available literature evidence including its neuroprotective action, Ocimum basilicum L may be qualified to be in this potential list. Therefore, we believe that the current comprehensive review may provide wealth of valuable information to serve as a resource for ethno medicine derived pharmotherapeutical discovery for the treatment of NDs. Among herbal plants, Ocimum species or known as basil which belongs to the Lamiaceae family is in use traditionally for a longer period to treat various illnesses [104]. The distribution of Ocimum species is commonly found in tropical regions of America, Asia, and Africa because of the favorable warm condition for their growth [105]. The reason for various geographic distribution as well as the generic variation of this genus is described by [106]. Numerous therapeutic properties of Ocimum species are due to the presence of certain bioactive compounds within the plants. There 
are few important Ocimum species only investigated until now for their phytochemical screening or medicinal properties, which include $O$. sanctum, O. basilicum, $O$. gratissimum, O. suave, O. americanum, and $O$. canum [107].

O. basilicum L (Fig. 1) also called sweet basil with numerous vernacular names [108-110] is well practiced in various traditional healthcare systems [111-115]. $O$. basilicum plants were obtained from local plantation in Gombak, Kuala Lumpur, Malaysia and a voucher specimen (HF100) was deposited and plant authentication was done at the Herbarium, Bangi [116]. It has exhibited various pharmacological properties such as antiulcerogenic, anti-inflammatory, anti-microbial [117, 118], anti-asthmatic [119], and anti-carcinogenic/chemotherapeutic [120] activities. Besides, analgesic [121], antipyretic, anti-diabetic/hypolipidemic [122], digestive, hepatoprotective [123], anti-stress, and immunomodulatory [124], lipid lowering, and hypoglycemic [122, 125] activities of this potential plant is described in Fig. 2.

\section{Bioactive principles and chemical composition of $O$. basilicum $\mathrm{L}$.}

Several studies have reported the major phytochemical composition of O. basilicum L. [122], which exhibited the presence of various phytoconstituents during the preliminary screening on the extract of $O$. basilicum in leaves including alkaloids, glycoside, gums mucilage, planteose, polysaccharides, proteins, amino acids, tannins, phenolic compounds, triterpenoids, steroids, sterols, saponins, flavones, and flavonoids. Besides the above, various other compounds such as tannins, saponin, alkaloids, phenolic compounds, flavonoids, glycosides, steroids, protein, and amino acids are also

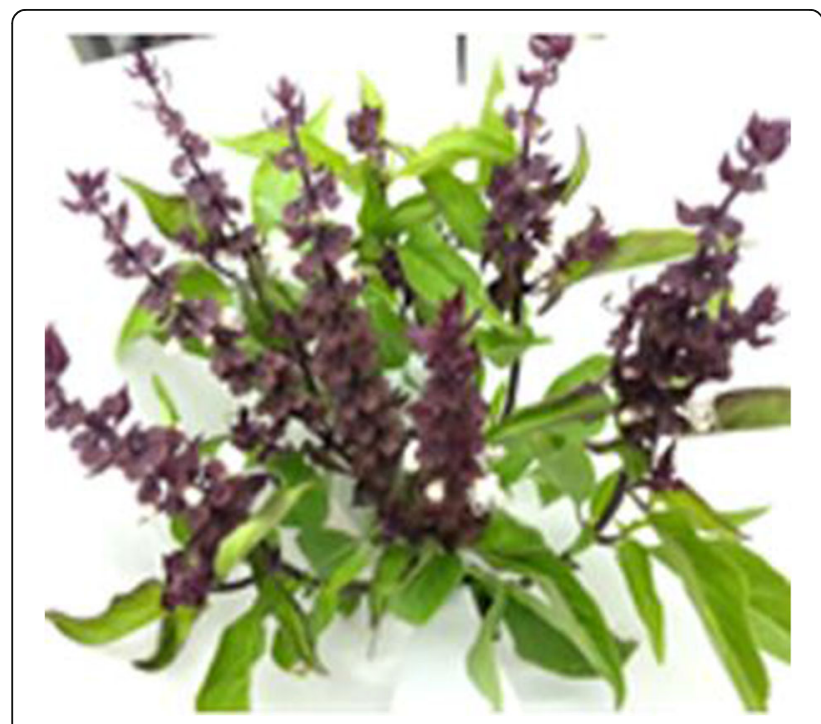

Fig. 1 Ocimum basilicum Linn reported [126] except phenolic compounds. It is important to note that the extraction, isolation, as well as identification of chemical compounds are the crucial step. The presence of various phytocompounds within $O$. basilicum shows that different types of extraction methods affect its phytoconstituent detections and different parts of the plant exhibited different active compounds within the extract [110]. To support the above, leaves extracted by both hydro-distillation and $n$-hexane showed the presence of eugenol derivatives [127, 128] and high linalool content only by GC/MS analysis [129].

The unique aroma found in various species of $O$. basilicum is due to the presence and various compositions of their essential oils (EO). Seeds are rich in oil content and consist of varying concentrations and types like 50\% linoleic acid, 22\% linolenic acid, 15\% oleic acid, and $8 \%$ unsaturated fatty acids. The following are the most prominent reported EO of basil $\alpha$ terpineol, linalool, $\beta$-elemene, germacrene $\mathrm{D}, \alpha$ bergamotene, $\alpha$-guaiene, eucalyptol, cubenol, $\tau$ cadinol, eugenol, methyl eugenol, camphor, bornylacetate, $\alpha$-caryophyllene, $\beta$-caryophyllene, elixen, $\beta$ cadinene $[105,121,130]$. But to a lesser extent, leaves have oleanolic acid and parts of ursolic acid, whereas dried leaves and flower tops contain essential oils other than protein (14\%), carbohydrates (61\%), high concentration of vitamin $\mathrm{A}$ and $\mathrm{C}$, rosmarinic acid, and xanthomicrol [108]. Besides, flavonoid glycosides and aglycones as well as three different kinds of flavones like eriodictyol, eriodictyol-7-glucoside, and vicenin-2 have also reported. A study conducted by [131] found the variance among phenolic compounds and suggested that the difference may be attributed for different vegetation period. However, the presence of major components like caffeic acid and rosmarinic acid is observed in all the stages of plant growth. These findings suggest that the presence of rosmarinic acid as the most prevalent phenolic compound in O. basilicum L. Rosmarinic acid is one of the important phenolic compounds, which exhibit antiviral, antibacterial, anti-inflammatory, as well as antioxidant properties [132]. In addition, $\beta$-sitosterol (steroids), tannins, and polyphenols $(2.2-2.3 \%)$ have reported in O. basilicum L. Figure 3 shows molecular structure of rosmarinic acid a representative candidate of O. basilicum L.

Numerous confirmative investigations on drug discovery and development, mostly on medicinal plants, have demonstrated their neuroprotective efficacy through numerous cellular and molecular signaling pathways on different types of NDs [133]. In this regard, [134] reported that many kinds of chemical constituents (e.g., diterpenes and cyclodepsipeptides) identified as key components to interact with the GABAA receptor 


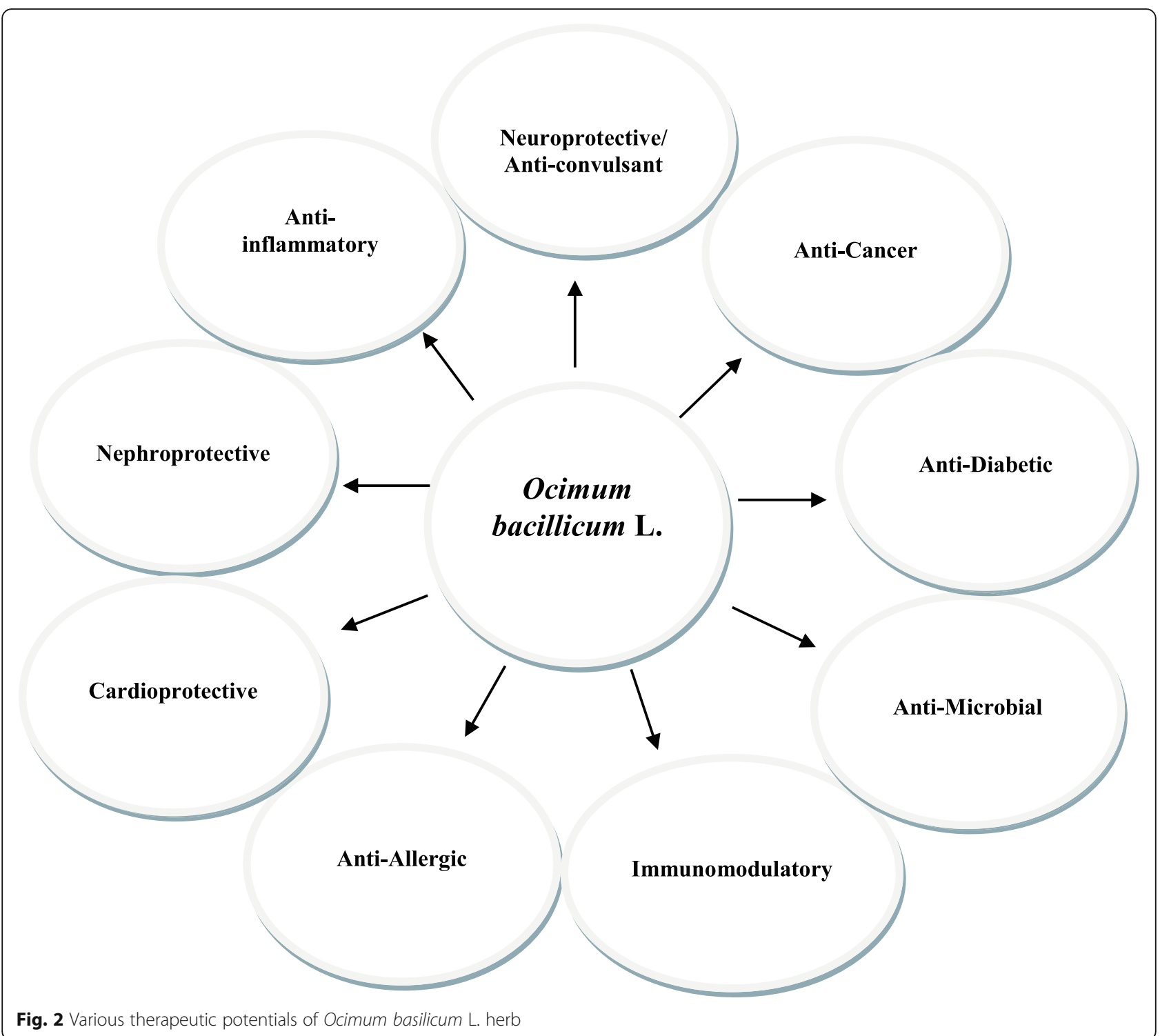

Fig. 2 Various therapeutic potentials of Ocimum basilicum L. herb<smiles>O=C(/C=C/c1ccc(O)c(O)c1)O[C@H](Cc1ccc(O)c(O)c1)C(=O)O</smiles>

Fig. 3 Structure of Rosmarinic acid $\left(\mathrm{C}_{18} \mathrm{H}_{16} \mathrm{O}_{8}\right)$, a representative prominent bioactive principle of $O$. basilicum $L$ selectively inhibit its activity [135]. In addition, alkaloids firmly regulate the interaction of bioactive principle muscimol with GABA receptor complex [136, 137]. Similarly, some phytochemicals like flavonoids also proven their binding ability on the GABAA receptor specifically at the benzodiazepine site $[138,139]$ and established as a scavenger against pro-inflammatory and neurotoxic radical species [140]. Moreover, many medicinal plants such as Mentha arvensis, Arisaema amurense, Salvia miltiorrhiza, Glycyrrhiza uralensis Biota orientalis, Albizia julibrissin, and Astragalus membranaceus have proven their inhibitory efficacy on monoamine oxidase-B (MAOB) enzyme [141].

Previous results obtained from various experimental results found that $\alpha$-asarone, a compound isolated from Acorus gramineus, exhibits its anti-convulsing, antileptic, as well as sedative action in the hippocampus of 
CNS by increasing tonic GABAergic neuronal activity $[142,143]$. Besides, the abundance of natural polyphenol especially flavonoids present in fruits and other cruciferous vegetables exhibited their anti-inflammatory, antiseizure, and antiepileptic activities by modulating allosteric GABAA receptors in pentylenetetrazole-induced seizure model animal studies $[144,145]$. To support this, naringenin 4'7-dimethyl ether has also shown its effectiveness against various types of available acute seizure mice models like $6 \mathrm{Hertz}(\mathrm{Hz})$ psychomotor seizure model and timed intravenous pentylenetetrazole convulsive seizure model [146]. Thus, it clearly shows that the naringenin methylation process has augmented the efficiency of anti-leptic actions against various seizure models.

Several Ocimum species have been investigated for their medicinal properties [147-150]. Figure 4 depicts some of the important therapeutic properties and preventive mechanisms. To support this, the aqueous extract derived from $O$. basilicum L. and its flavonoids, orintin, apigenin, carnosic acid, vicenin, and eugenol have shown to protect $\gamma$ radiation-induced mortality in mice but selectively protect the normal tissues [148, 149]. In addition, Ocimum spp. containing EO-rich phenolic compounds and anthocyanins exhibit wide spectrum of therapeutic use [151, 152]. Many studies have isolated EO from O. basilicum L. and reported its various prominent volatile components [153-157]. These compounds have demonstrated anticonvulsant effects [158] and CNS depressant activity [159] in pentylenetetrazol-induced animal model seizures but not in the strychnine-induced seizures. Moreover, the action of EO was reversed by flumazenil (agonist of GABAA receptor) corroborate the results that O. basilicum L. EO exerts its anti-convulsing action by specifically targeting GABAAergic mechanism [133, 160]. Normally, strychnine antagonizes glycine receptor activity by stimulating convulsions and enhances post-synaptic excitability and subsequent activities in the brain stem and spinal cord without involvement of GABA receptor [161].

Despite knowing the pathogenesis of NDs in the specific region of the brain, the poor antioxidant defence system together with the excessive ROS generation are unifying distinct factors responsible for progressive neuronal death $[18,162]$. Simultaneously, a growing interest on the neuroprotective and antioxidant potentials of herbal supplements, medicinal plants, which include $O$. basilicum $L$ and their bioactive principles require further exploration and detailed discussion on specific cellular and molecular mechanisms. In this regard, rosmarinic acid obtained from Rosmarinus officinalis and Ocimum species strongly exhibited its action against oxidative molecules [163] by inhibiting lipid peroxidation and maintaining cell membrane integrity without altering cell structures [164]. The neuroprotective efficacy of rosmarinic acid $(100 \mathrm{mg} / \mathrm{kg})$ was demonstrated using Kainic acid-induced (agonist of AMPA/KA receptor) temporal lobe epilepsy in rats [165-167] and ethanol-induced geno-toxicity in mice [168]. In vitro studies employing rosmarinic acid in N2A cells have also shown the similar neuro-protective properties [169].

In addition, cells treated with rosmarinic acid exhibits concentration-dependent protective properties in hydrogen peroxide $\left(\mathrm{H}_{2} \mathrm{O}_{2}\right)$-induced oxidative stress by reducing ROS generation and cell loss [170-173]. The actions were similar to caffeic acid and shown its neuroprotective action by enhancing learning and memory in the inhibitory avoidance tasks (avoiding specific tasks) by reducing acetyl cholinesterase (AChE) level [174176]. Furthermore, a observation has also revealed the neuroprotective actions of rosmarinic acid, which are mostly evident by the upregulation of protective genes, brain-derived neurotrophic factor (BDNF), tyrosine hydroxylase $(\mathrm{TH})$ levels, and prevent mitochondrial dysfunction [169]. In line with this, eugenol, another important phytocomponent present in EO of O. basilicum and other species of Ocimum and clove oil [177, 178], has shown strong antioxidant activities [179] and exhibiting reduced level of calcium and AChE activity [178]. Furthermore, EO has shown to reduce neuronal loss and lactate dehydrogenase enzyme release in $\mathrm{N}$-methyl-D-aspartate (NMDA)-induced neurotoxicity [180, 181].

Though previous results have demonstrated that individual compounds of $O$. basilicum have shown their neuroprotective efficacy in numerous neurodegenerative animal models; however, one can possibly expect an alternative approach of employing crude extracts or applying combination of bioactive principles for the NDs treatment. By adopting this approach, many signaling mechanisms including antioxidant activity enhanced and mediated by the synergism efforts. Besides, O. Basilicum-derived phytocompounds prevent cerebral ischemia, reperfusion, and short-term memory loss and improve motor performance [173-175]. Results of above investigations suggest that the neuro-protection may be owing to the existence of tannins, phenols, and flavonoids [182]. To support this, mice administrated with the extract of $O$. basilicum at the concentration ranging from 200 to $400 \mathrm{mg} / \mathrm{kg}$ for 7 days reversed the scopolamine-induced memory loss when compared to other drug standard drug tacrine. These reversal behavioral actions accompanied by reduced acetyl cholinesterase (AChE) and thiobarbituric acid reactive substances (TBARS) and increased glutathione levels in both the cortex and hippocampus. In addition, focal gliosis, increased vacuolation, and lesser number of pyramidal cells were also evident. 


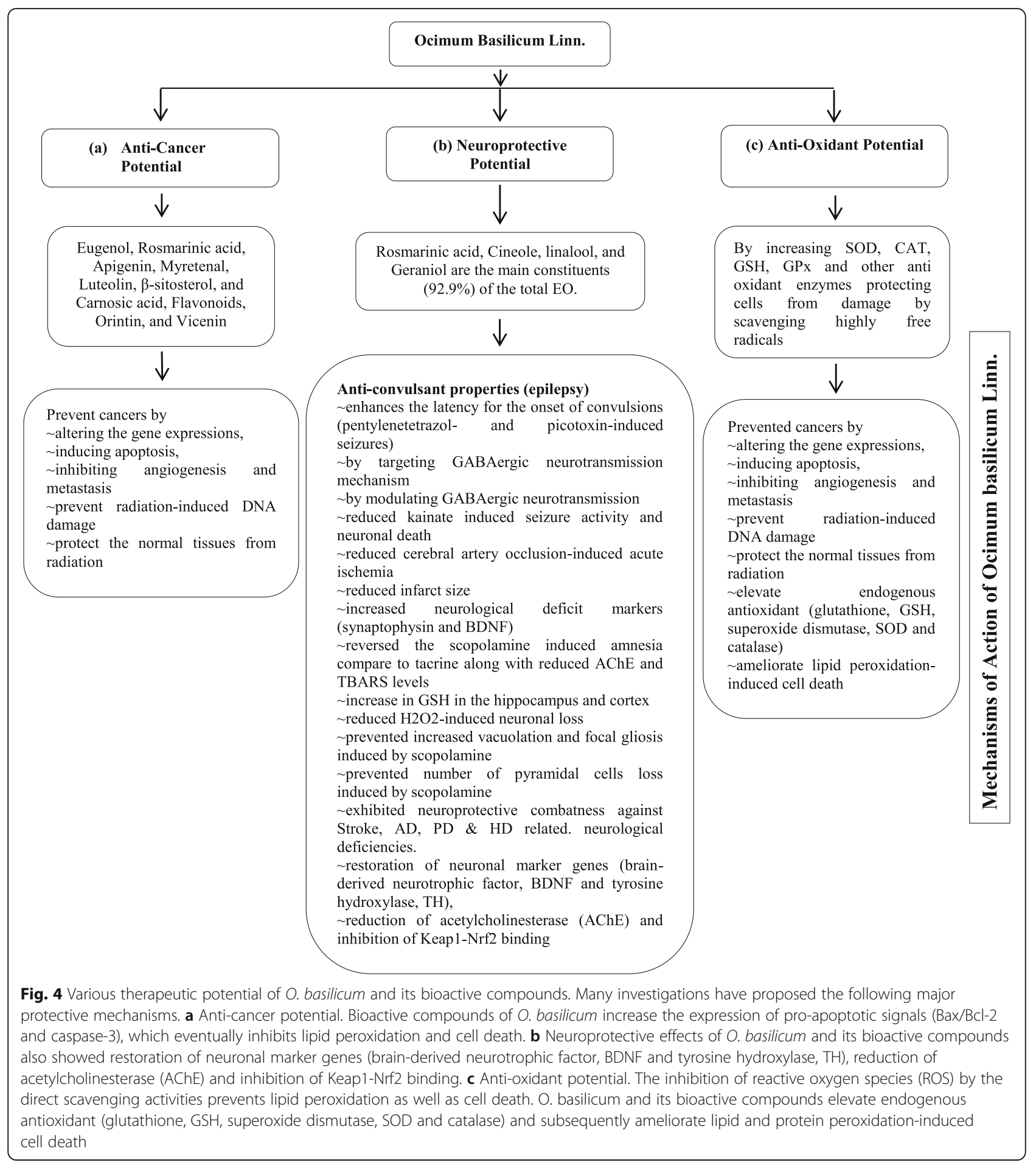

Meanwhile, oxidative stress is an important death signal contributor of NDs by causing cell death or apoptosis [18]. Free radical stress occurs when oxidant level is more with diminished antioxidant defence system found in our body. Though natural antioxidant enzymes such as SOD and glutathione (GSH) are available in our body, yet the exogenous antioxidants are still required through diets. Rather than antioxidant, antimicrobial, as well as antitumor, the extract of $O$. basilicum L. also showed neuro-protective effects which generally beneficial to combat neurological deficiencies such as Stroke, Alzheimer's, Parkinson's, as well as Huntington's disease. Singh et al. [182] demonstrated that pre-treatment of ethyl acetate extract of $O$. basilicum Linn. on mice could 


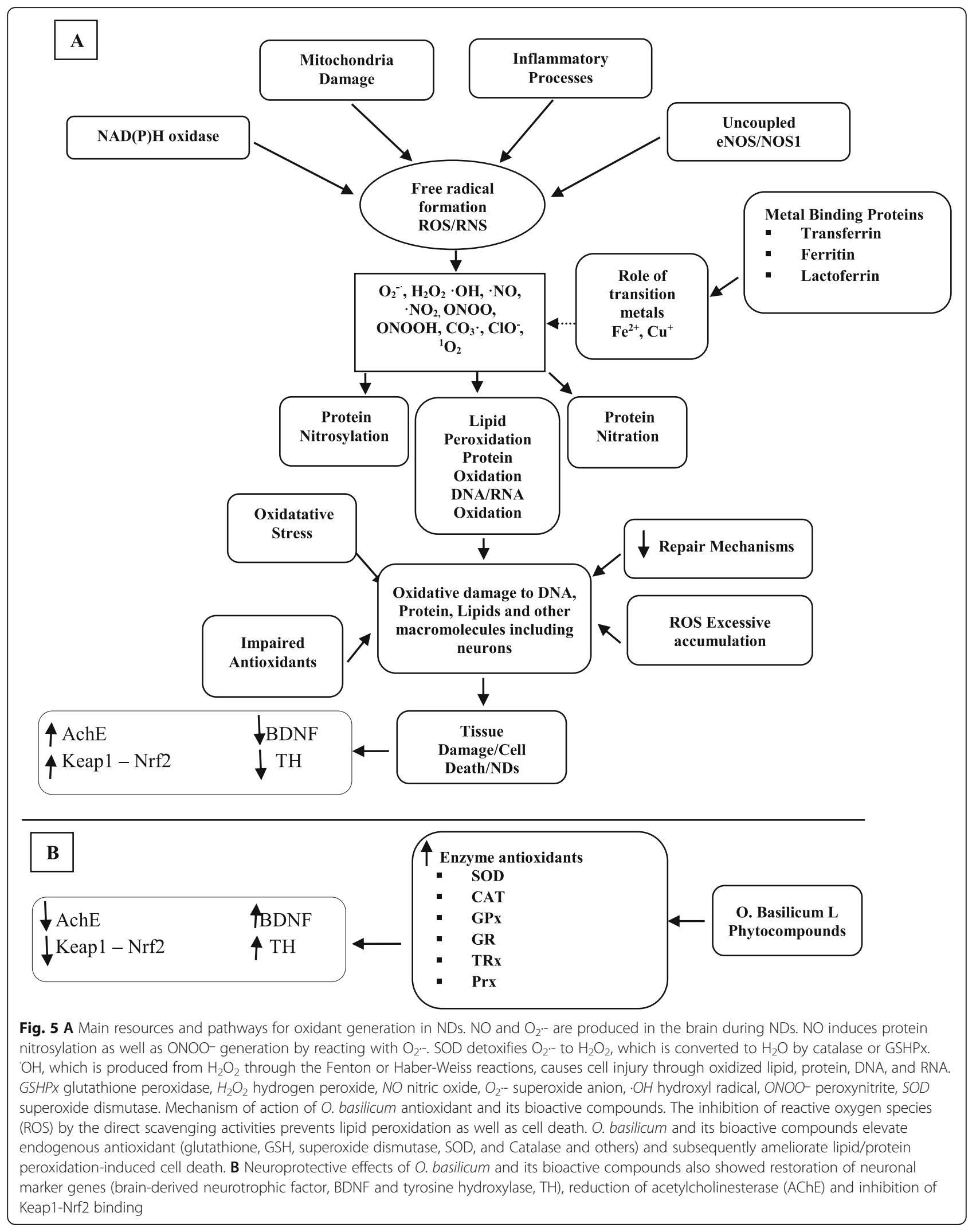


prevent neuron injury in mice induced by reperfusion cerebral damage. Reperfusion-injury introduces oxidative stress among mice, which is one of the mechanisms for neuro-degeneration diseases. Figure 5 describes the main resources and pathways for oxidant generation in NDs and $O$. basilicum and its bioactive compounds antioxidant mechanisms and neuro-protective effects. Many extensive reports suggest that $O$. basilicum Linn. a traditionally grown medicinal herb may become a potential therapy for NDs by acting as a neuro-protective agent, since it possesses antioxidant properties, which could help to prevent oxidative stress by scavenging the oxidation reactions and hence avoid cell apoptosis and cell death.

\section{Conclusions}

Although there has been great advancement in understanding the etiologies of most NDs, but no complete remedies or cure for them yet. However, many extensive attempts have been made to understand the pathophysiology of these diseases along with the available treatment interventions to discover new therapeutic options for NDs. NDs complicated nature with a substantial memory loss and quality of life especially among elderly patients occurring frequently in the developed nations but the same trend also witnessed recently in developing countries world-wide. Besides, current therapeutic regimens are also not effective for these problems because of their poor clinical outcome. Despite the world has witnessed tremendous advancement on the current therapeutics availability for the management of NDs, still the field is in its infancy, in terms of research efforts, in adequate outputs, and resource utilization. However, on the positive side, the application of traditional medicinal herbs have increased in recent years and contributed their righteous share for NDs treatment. By adapting multidisciplinary multi-center research approaches with the inclusion of appropriate clinical trials using bioactive principles may provide potential solutions to address and manage this severe complex disease.

In summary, many plant extracts have been shown as a promising source of novel drug discovery by traditional medical practitioners for years to cure various diseases. Among these plants, the Ocimum species have been known worldwide as a potential herb with numerous health benefits. This review revealed the genus of Ocimum, some therapeutic potential of Ocimum species, which mainly focused on O. basilicum Linn. and its phytocompounds. So far, only a limited number of secondary metabolites have been identified within Ocimum species. Hence, further investigations are required on various known and unknown bioactive principles of Ocimum species, which include O. basilicum L. Since these biological constituents are highly valuable to the pharmaceutical industries in formulating new drugs for various disease treatment. Finally, the authors conclude that this plant may serve as promising therapeutics for the treatment of NDs.

\section{Abbreviations}

NDs: Neurodegenerative diseases; SOD: Superoxide dismutase;

GSH: Glutathione; AChE: Acetyl cholinesterase; TBARS: Thiobarbituric acid reactive substances; NMDA: $\mathrm{N}$-methyl-D-aspartate; TH: Tyrosine hydroxylase; BDNF: Brain-derived neurotrophic factor; $\mathrm{H}_{2} \mathrm{O}_{2}$ : Hydrogen peroxide;

ROS: Reactive oxygen species; AMPA: a-Amino-3-hydroxy-5-methyl-4isoxazolepropionic acid; KA: Kainic acid; GABA: Gamma aminobutyric acid; CNS: Central nervous system; EO: Essential oil; MAOB: Mono-amine oxidase-B; GC-MS: Gas chromatography-mass spectrometry; NF-kB: Nuclear factor kappa B; APOE-ع4: Apolipoprotein E; AD: Alzheimer disease; PD: Parkinson's disease; HD: Huntington's disease; IFN- $\gamma$ : Interferon gamma; MAPK: Mitogen-activated protein kinase; L-DOPA: I-3,4-Dihydroxyphenylalanine; PUFAs: Polyunsaturated fatty acids; APP: Amyloid protein precursor; PSEN 1, 2: Presenilin-1, 2

\section{Acknowledgements}

Not applicable.

\section{Plant authentication}

O. basilicum plants were obtained from local plantation in Gombak, Kuala Lumpur, Malaysia and a voucher specimen (HF100) was deposited and appropriate plant authentication was done at the Herbarium, Bangi by a coauthor NA.

\section{Authors' contributions}

MAS inscribed the major part of the manuscript contributed to the guiding and configuring of the manuscript. SA, NA, FMA, AIA, OAZ, and $\mathrm{YH}$ contributed to the writing of the manuscript in various segments. All authors have read and approved the manuscript.

Funding

Not applicable (no funding support available for this review).

Availability of data and materials

Not applicable.

\section{Declarations}

Ethics approval and consent to participate

Not applicable.

Consent for publication

Not applicable.

\section{Competing interests}

The authors declare that they have no competing interests.

\section{Author details}

${ }^{1}$ Department of Biochemistry, Faculty of Science, University of Tabuk, Tabuk 71491, Kingdom of Saudi Arabia. ${ }^{2}$ School of Public Health, SRM University, Kattankulathur, Chennai, Tamil Nadu, India. ${ }^{3}$ Faculty of Pharmacy, Universiti Kebangsaan Malaysia, Jalan Raja Muda Abdul Aziz, 50300 Kuala Lumpur, Malaysia. ${ }^{4}$ Department of Biology, Faculty of Science, University of Tabuk, Tabuk 71491, Kingdom of Saudi Arabia. ${ }^{5}$ College of Medicine, Al-Faisal University, P.O. Box 50927, Riyadh 11533, Saudi Arabia.

Received: 29 April 2021 Accepted: 29 June 2021

Published online: 08 July 2021

\section{References}

1. Burgunder J, Gasser T, Harbo H, Finsterer J (2010) Overview of the New European Federation of Neurological Societies' Guidelines on Molecular Diagnosis of Neurological Disorders. Eur Neurol Rev 5:12-17. https://doi. org/10.17925/ENR.2010.05.02.12

2. Heemels MT (2016) Neurodegenerative diseases. Nature 539(7628):179. https://doi.org/10.1038/539179a

3. GBD (2017) Neurological disorders collaborator group. Global, regional, and national burden of neurological disorders during 1990-2015: A systematic 
analysis for the global burden of disease study 2015. Lancet Neurol 16:877897. https://doi.org/10.1016/S1474-4422(17)30299-5

4. Hung CW, Chen YC, Hsieh WL, Chiou SH, Kao CL (2010) Ageing and neurodegenerative diseases. Ageing Res Rev 9:S36-S46

5. Delnooz CCS, van de Warrenburg BPC (2012) Current and future medical treatment in primary dystonia. Ther Adv Neurol Disord 5(4):221-240

6. Mehan S, Sharma D, Sharma G, Arora R, Sehgal V (2012) Dementia-a complete literature review on various mechanisms involves in pathogenesis and an intracerebroventricular streptozotocin induced Alzheimer's disease. INTECH Open Access Publisher Available online at: http://www.intechopen. com/books/inflammatory-diseases-immunopathology-clinical-and-pharma cologicalbases/alzheimer-s-disease-an-updated-review-on-pathogenesis-andintracerebroventricular-streptozotocin-ind

7. Erkkinen MG, Kim MO, Geschwind MD (2018) Clinical neurology and epidemiology of the major neurodegenerative diseases. Cold Spring Harb Perspect Biol 10(4). https://doi.org/10.1101/cshperspect.a033118

8. Burgunder JM (2003) Neurodegeneration. IUBMB Life 55(6):291. https://doi. org/10.1080/1521654031000153007

9. Katsnelson A, De Strooper B, Zoghbi HY (2016) Neurodegeneration: From cellular concepts to clinical applications. Sci Transl Med 8(364):364ps18. https://doi.org/10.1126/scitranslmed.aal2074

10. Migliore L, Coppede F (2009) Genetics, environmental factors and the emerging role of epigenetics in neurodegenerative diseases. Mutat Res 667: 82-97. https://doi.org/10.1016/j.mrfmmm.2008.10.011

11. Stefanis L (2012) a-Synuclein in Parkinson's disease. Cold Spring Harb Perspect Med 2(2):a009399. https://doi.org/10.1101/cshperspect.a009399

12. Held P (2012) An introduction to reactive oxygen species: measurement of ROS in cells (white paper). BioTek Instruments, Inc, Winooski

13. Mani S (2015) Production of reactive oxygen species and its implication in human diseases. In: Rani V, Yadav UC (eds) Free radicals in human health and disease. Springer, New Delhi, pp 3-15

14. Harman D (1956) Aging: a theory based on free radical and radiation Chemistry. J Gerontol 11(3):298-300. https://doi.org/10.1093/geronj/11.3.298

15. Mattson MP (2000) Apoptosis in neurodegenerative disorders. Nat Rev Mol Cell Biol 1:120-129

16. Uttara B, Singh AV, Zamboni P, Mahajan RT (2009) Oxidative stress and neurodegenerative diseases: a review of upstream and downstream antioxidant therapeutic options. Curr Neuropharmacol 7(1):65-74

17. Cobb C, Cole M (2015) Oxidative and Nitrative Stress in Neurodegeneration. Neurobiol Dis 84:4-21

18. Chamulitrat W, Mason RP (1989) Lipid peroxyl radical intermediates in the peroxidation of polyunsaturated fatty acids by lipoxygenase. Direct electron spin resonance investigations. J Biol Chem 264(35):20968-20973

19. Dasuri K, Zhang L, Keller JN (2013) Oxidative stress, neurodegeneration, and the balance of protein degradation and protein synthesis. Free Radic Biol Med 62:170-185

20. Gandhi S, Abramov AY (2012) Mechanism of oxidative stress in neurodegeneration, oxidative medicine and cellular longevity. 428010:11. https://doi.org/10.1155/2012/428010

21. Song P, Zou MH (2012) Regulation of NAD(P)H oxidases by AMPK in cardiovascular systems. Free Radic Biol Med 52(9):1607-1619

22. Wang X, Michaelis EK (2010) Selective neuronal vulnerability to oxidative stress in the brain. Front Aging Neurosci 2:12. https:/doi.org/10.3389/fnagi.2010.00012

23. Ferreira ME, de Vasconcelos $A S$, da Costa VT, da Silva $T L$, da Silva BA, Gomes AR, Dolabela MF, Percário S (2015) Oxidative Stress in Alzheimer's Disease: Should We Keep Trying Antioxidant Therapies? Cell Mol Neurobiol 35(5): 595-614. https://doi.org/10.1007/s10571-015-0157-y

24. Breydo L, Wu JW, Uversky VN (2012) a-Synuclein misfolding and Parkinson's disease. Biochim Biophys Acta (BBA) - Mol Basis Dis 1822(2):261-285. https:// doi.org/10.1016/j.bbadis.2011.10.002

25. Baldi I, Lebailly P, Mohammed B, Letenneur L, Dartigues JF, Brochard P (2003) Neurodegenerative diseases and exposure to pesticides in the elderly. Am J Epidemiol 157(5):409-414. https://doi.org/10.1093/aje/kwf216

26. Solfrizzi V, Capurso C, Introno AD, Colacicco AM, Santamato A, Ranieri M, Fiore P, Capurso A, Panza F (2008) Lifestyle-related factors in predementia and dementia syndromes. Expert Rev Neurother 8(1):133-158. https://doi. org/10.1586/14737175.8.1.133

27. Dobson CM, Sali A, Karplus M (1998) Protein folding-a perspective from theory and experiment. Angew Chem Int Ed Eng 37:868-893

28. Bartlet Al, Radford SE (2009) An expanding arsenal of experimental methods yields an explosion of insights into protein folding mechanisms. Nat Struct Mol Biol 16:582-588
29. Hartl FU, Hartl MH (2009) Converging concepts of protein folding in vitro and in vivo. Nat Struct Mol Biol 16(6):574-581

30. Qiu C, Kivipelto M, von Strauss E (2009) Epidemiology of Alzheimer's disease: occurrence, determinants, and strategies toward intervention. Dialogues Clin Neurosci 11:111-128

31. Morimoto RI (2008) Roteotoxic stress and inducible chaperone networks in neurodegenerative disease and aging. Genes Dev 22(11):1427-1438

32. Pegoraro G, Voss TC, Martin SE, Tuzmen P, Guha R, Misteli T (2012) Identification of mammalian protein quality control factors by highthroughput cellular imaging. PLOS ONE 7(2):e31684

33. Dobson CM (2006) Protein aggregation and its consequences for human disease. Protein Pept Lett 13(3):219-227

34. Lin X, Zhang N (2018) Berberine: pathways to protect neurons. Phytother Res 32(8):1501-1510

35. Tewari D, Stankiewicz AM, Mocan A, Archana NS, Tzvetkov NT, Huminiecki L, Horbańczuk JO, Atanasov AG (2018) Ethnopharmacological approaches for dementia therapy and significance of natural products and herbal drugs. Front Aging Neurosci 10:3. https://doi.org/10.3389/fnagi.2018.00003

36. Mohamed Ali S, Vijayaraghavan K, Rajkumar J, Bukhari SN, Al-Sayed B (2017) Chromolaena odorata: a neglected weed with a wide spectrum of pharmacological activities (Review). Mol Med Rep 15(3):1007-1016

37. MohamedAli S (2019) A comprehensive review on Phyllanthus derived natural products as potential chemotherapeutic and immunomodulators for a wide range of human diseases. Biocat Agri Biotechnol 17:529-537

38. MohamedAli S, Sddiqua A (2020a). Calotropis - a multi-potential plant to humankind: Special focus on its wound healing efficacy. Biocat Agri Biotechnol 28: 101725. https://doi.org/10.1016/j.bcab.2020.101725

39. Mohamed Ali S, Siddiqua A (2020b) Modern phytomedicine in treating diabetic foot ulcer: progress and opportunities. In: Zubair BM et al (eds) Diabetic Foot Ulcer, (Chapter 18): Diabetic Foot Ulcer. Springer, Singapore, pp 281-313

40. Kimura I (2006) Medical benefits of using natural compounds and their derivatives having multiple pharmacological actions. Yakugaku Zasshi 126(3):133-143

41. Karimi A, Majles M, Mahmoud RK (2015) Herbal versus synthetic drugs; beliefs and facts. J Nephropharmacol 4(1):27-30

42. Pan SY, Zhou SF, Gao SH, Yu ZL, Zhang SF, Tang MK, Sun JN, Ma DL, Han YF, Fong WF, Ko KM $(2013,2013)$ New perspectives on how to discover drugs from herbal medicines: CAM's outstanding contributioto modern therapeutics. Evid Based Complement Alternat Med 627375. Published online 2013 Mar 24. https://doi.org/10.1155/2013/627375

43. Gordon MC, David JN (2013) Natural products: a continuing source of novel drug leads. Biochim Biophys Acta. Author manuscript; available in PMC 2014 Jun 1. Published in final edited form as: Biochim Biophys Acta 1830(6):36703695. https://doi.org/10.1016/j.bbagen.2013.02.008

44. Hughes JP, Rees S, Kalindjian SB, Philpott KL (2011) Principles of early drug discovery. Br J Pharmacol 162(6):1239-1249

45. Pawel S, Magdalena M, Elżbieta MO (2012) Adaptation of high-throughput screening in drug discovery-toxicological screening tests. Int J Mol Sci 13(1): 427-452. https://doi.org/10.3390/ijms13010427

46. Macarrón R, Hertzberg RP (2011) Design and implementation of high throughput screening assays. Mol Biotechnol 47:270-285

47. Veeresham C (2012) Natural products derived from plants as a source of drugs. J Adv Pharm Technol Res 3(4):200-201. https://doi.org/10.41 03/2231-4040.104709

48. Raskin I, Ribnicky D, Komarnytsky S, Neboj PA, Borisjuk N, Brinker A, Moreno DA, Ripoll C, Yakoby N, O'Neal J, Cornwell T, Pastor I, Fridlender B (2003) Plants and human health in the twenty-first century. Trends Biotechnol 20: 522-531

49. Long F, Yang $H, X u Y$, Hao H, Li P (2015) A strategy for the identification of combinatorial bioactive compounds contributing to the holistic effect of herbal medicines. Sci Rep 5:12361. https://doi.org/10.1038/srep12361

50. Fazili NA, Naeem A, Ashraf GM, Hua GS, Kamal MA (2015) Therapeutic interventions for the suppression of Alzheimer's disease: quest for a remedy. Curr Drug Metab 16(5):346-353

51. Dey A, De JN (2015) Neuroprotective therapeutics from botanicals and phytochemicals against Huntington's disease and related neurodegenerative disorders. J Herb Med 5(1):1-19

52. Elufioye TO, Berida TI, Habtemariam S (2017) Plants-derived neuroprotective agents: cutting the cycle of cell death through multiple mechanisms. EvidBased Comple Alter Med 3574012:27. https://doi.org/10.1155/2017/3574012 
53. Dubey S, Gautam S, Kowthavarapu K, Tejas A, Ranendra S, Gaurav G (2018) Herbal medicines in neurodegenerative disorders: an evolutionary approach through novel drug delivery system. J Environ Pathol Toxicol Oncol 37. https://doi.org/10.1615/JEnvironPatholToxicolOncol.2018027246

54. Di Paolo M, Papi L, Gori F, Turillazzi E (2019) Natural products in neurodegenerative diseases: a great promise but an ethical challenge. Int J Mol Sci 20(20):5170

55. Zhou X, Seto SW, Chang D, Kiat H, Razmovski-Naumovski V, Chan K, Alan B (2016) Synergistic effects of chinese herbal medicine: a comprehensive review of methodology and current research. Front Pharmacol 7:201. https://doi.org/10.3389/fphar.2016.00201

56. Bhat SA, Kamal MA, Yarla NS, Ashraf GM (2017) Synopsis on managment strategies for neurodegenerative disorders: Challenges from bench to bedside in successful drug discovery and development. Curr Top Med Chem 17(12):1371-1378

57. Dadhania VP, Trivedi PP, Vikram A, Tripathi DN (2016) Nutraceuticals against neurodegeneration: a mechanistic insight. Curr Neuropharmacol 14(6):627640

58. Kumar GP, Khanum F (2012) Neuroprotective potential of phytochemicals. Pharmacogn Rev 6(12):81-90

59. Singh S, Dikshit M (2007) Apoptotic neuronal death in Parkinson's disease: involvement of nitric oxide. Brain Res Rev 54(2):233-250

60. Vasant MS, Kumar H, Kim IS, Koppulla S, Kim BW, Choi DK (2013) Strategic selection of neuroinflammatory models in Parkinson's disease: evidence from experimental studies. CNS Neurol Disord Drug Targets (Formerly Current Drug Targets-CNS \& Neurolo Disorder) 12(5):680-697

61. Fox SH, Brotchie JM (2010) The MPTP-lesioned non-human primate models of Parkinson's disease. Past, present, and future In Prog. Brain Res 184:133157

62. Bagli E, Goussia A, Moschos MM, Agnantis N, Kitsos G (2016) Natural compounds and neuroprotection: mechanisms of action and novel delivery systems. In Vivo 30(5):535-547

63. Wang ZY, Liu JY, Yang CB, Malampati S, Huang YY, Li MX, Li M, Song JX (2017) Neuroprotective natural products for the treatment of parkinson's disease by targeting the autophagylysosome pathway: a systematic review. Phytother Res 31(8):1119-1127. https://doi.org/10.1002/ptr.5834

64. Rahman I, Chung S (2010) Dietary polyphenols, deacetylases and chromatin remodeling in inflammation. J Nutrigenet Nutrigenomics 3(4-6):220-230

65. Harvey AL, Clark RL, Mackay SP, Johnston BF (2010) Current strategies for drug discovery through natural products. Expert Opin Drug Discovery 5(6): 559-568

66. Kimura I, Inoue D, Maeda T, Hara T, Ichimura A, Miyauchi S, Kobayashi M, Hirasawa A, Tsujimoto G (2011) Short-chain fatty acids and ketones directly regulate sympathetic nervous system via G protein-coupled receptor 41 (GPR41). Proc Natl Acad Sci U S A 108(19):8030-8035. https://doi.org/10.1 073/pnas.1016088108

67. Ansari R, Mahta A, Mallack E, Luo JJ (2014) Hyperhomocysteinemia and neurologic disorders: a review. J Clin Neurol 10(4):281-288

68. Braak H, Ghebremedhin E, Rüb U, Bratzke H, Del Tredici K (2004) Stages in the development of Parkinson's disease-related pathology. Cell Tissue Res 318(1):121-134

69. Sanders LH, McCoy J, Hu X, Mastroberardino PG, Dickinson BC, Chang CJ, Chu CT, Van Houten B, Greenamyre JT (2014) Mitochondrial DNA damage: Molecular marker of vulnerable nigral neurons in Parkinson's disease. Neurobiol Dis 70:214-223

70. Sayre LM, Smith MA, Perry G (2001) Chemistry and biochemistry of oxidative stress in neurodegenerative disease. Curr Med Chem 8(7):721-738

71. Mercuri NB, Bernardi G (2005) The 'magic' of L-dopa: why is it the gold standard Parkinson's disease therapy? Trends Pharmacol Sci 26(7):341-344

72. Mythri RB, Bharath MM (2012a) Curcumin: a potential neuroprotectiveagent in Parkinson's disease. Curr Pharm Des 18(1):91-99

73. Mythri RB, Harish G, Bharath MM (2012b) Therapeutic potential of natural products in Parkinson's disease. Recent Pat Endocr Metab Immune Drug Discov 6(3):181-200

74. Kandinov B, Giladi N, Korczyn AD (2009) Smoking and tea consumption delay onset of Parkinson's disease. Parkinsonism Relat Disord 15(1):41-46

75. Leonoudakis D, Rane A, Angeli S, Lithgow GJ, Andersen JK, Chinta SJ (2009) Smoking and tea consumption delay onset of Parkinson's disease. Parkinsonism Relat Disord 15(1):41-46

76. Sawa A, Tomoda T, Bae Bl (2003) Mechanisms of neuronal cell death in Huntington's disease. Cytogenet Genome Res 100(1-4):287-295
77. Kumar A (2010) Huntington's disease: pathogenesisto animal models. Pharmacol Rep 62(1):1-14

78. Krobitsch S, Kazantsev AG (2011) Huntington's disease: from molecular basis to therapeutic advances. Int J Biochem Cell Biol 43(1):20-24

79. Singhal AK, Naithani V, Bangar OP (2012) Medicinal plants with apotential to treat Alzheimer and associated symptoms. Int J Nutr Pharmacol Neurol Dis 2(2):84

80. Farrer LA, Cupples LA, Wiater P, Conneally PM, Gusella JF, Myers RH (1993) The normal Huntington disease (HD) allele, or a closely linked gene, influences age at onset of HD. Am J Hum Genet 53(1):125-130

81. Farooqui T, Farooqui AA (2009) Aging: an important factor for thepathogenesis of neurodegenerative diseases. Mech Ageing Dev 130(4): 203-215

82. Dong XX, Wang Y, Qin ZH (2009) Molecular mechanisms of excitotoxicity and their relevance to pathogenesis of neurodegenerative diseases. Acta Pharmacol Sin 30(4):379-387

83. Wu PF, Zhang Z, Wang F, Chen JG (2010) Natural compounds from traditional medicinal herbs in the treatment of cerebral ischemia/ reperfusion injury. Acta Pharmacol Sin 31(12):1523-1531

84. Sandhya S, Vinod K, Kumar S (2010) Herbs used for brain disorders. Hygeia J Drugs Med 2:38-45 (Sandhya.S et all, HygeiaJ.D.Med, vol.2 (1) 2010). muw.hygeiajournal.com

85. Shinomol GK, Muralidhara (2011) Bacopa monnieri modulates endogenous cytoplasmic and mitochondrial oxidative markers in prepubertal mice brain. Phytomed 18(4):317-326

86. Allison AC, Cacabelos R, Lombardi VR, Alvarez XA, Vigo C (2001) Celastrol, a potent antioxidant and anti-inflammatory drug, as a possible treatment for Alzheimer's disease. Prog Neuro-Psychopharmacol Biol Psychiatry 25(7):1341-1357

87. Visioli F, Riso P, Grande S, Galli C, Porrini M (2003) Protective activity of tomato products on in vivo markers of lipid oxidation. Eur J Nutr 42(4):201206. https://doi.org/10.1007/s00394-003-0415-5

88. Baba NH, Antoniades K, Habbal Z (1999) Effects of dietary canola, olive, and linolenic acid enriched olive oils on plasma lipids, lipid peroxidation and lipoprotein lipase activity in rats. Nutr Res 19(4):601-612

89. Hsiao G, Fong TH, Tzu NH, Lin KH, Chou DS, Sheu JR (2004) A potent antioxidant, lycopene, affords neuroprotection against microglia activation and focal cerebral ischemia in rats. Vivo 18(3):351-356

90. Kumar P, Kumar A (2009) Effect of lycopene and epigallocatechin-3- gallate against 3-nitropropionic acid induced cognitive dysfunction and glutathione depletion in rat: a novel nitric oxide mechanism. Food Chem Toxicol 47(10):2522-2530

91. Kumar P, Padi SS, Naidu PS, Kumar A (2007a) Cyclooxygenase inhibition attenuates 3-nitropropionic acid-induced neurotoxicity in rats: possible antioxidant mechanisms. Fundam Clin Pharmacol 21(3):297-306. https://doi. org/10.1111/j.1472-8206.2007.00485.X

92. Raso GM, Meli R, Di Carlo G, Pacilio M, Di Carlo R (2001) Inhibition of inducible nitric oxide synthase and cyclooxygenase-2 expression by flavonoids in macrophage J774A.1. Life Sci 68(8):921-931. https://doi.org/1 0.1016/S0024-3205(00)00999-1

93. Ishige K, Schubert D, Sagara Y (2001) Flavonoids protect neuronal cells from oxidative stress by three distinct mechanisms. Free Radic Biol Med 30(4):433-446

94. Nishimura $M$, Okimura $Y$, Fujita $H$, Yano $H$, Lee J, Suzaki E, Inoue M, Utsumi K, Sasaki J (2008) Mechanism of 3-nitropropionic acid-induced membrane permeability transition of isolated mitochondria and its suppression by Lcarnitine. Cell Biochem Funct 26(8):881-891

95. Kumar P, Padi SS, Naidu PS, Kumar A (2007b) Possible neuroprotective mechanisms of curcumin in attenuating 3-nitropropionic acid-induced neurotoxicity. Methods Find Exp Clin Pharmacol 29(1):19-25

96. Kumar P, Padi SSV, Naidu PS, Kumar A (2006) Effect of resveratrol on 3nitropropionic acid-induced biochemical and behavioural changes: possible neuroprotective mechanisms. Behav Pharmacol 17(5-6):485-492

97. Berchtold NC, Cotman CW (1998) Evolution in the conceptualization of dementia and Alzheimer's disease: Greco-Roman period to the 1960 s. Neurobiol Aging 19(3):173-189

98. Brookmeyer R, Johnson E, Ziegler-Graham K, Arrighi HM (2007) Forecasting the global burden of Alzheimer's disease. Alzheimers Dement 3(3):186-191

99. Takahashi RH, Nagao T, Gouras GK (2017) Plaque formation and the intraneuronal accumulation of $\beta$-amyloid in Alzheimer's disease. Pathol Int 67(4):185-193. https://doi.org/10.1111/pin.12520

100. Szeto JY, Lewis SJJ, Lewis S (2016) Current treatment options for Alzheimer's disease and Parkinson's disease dementia. Curr Neuropharmacol 14(4):326338 
101. Behl C, Moosmann B (2002) Antioxidant neuroprotection in Alzheimer's disease as preventive and therapeutic approach. Free Radic Biol Med 33(2): 182-191. https://doi.org/10.1016/S0891-5849(02)00883-3

102. Pappolla MA, Chyan YJ, Omar RA, Hsiao K, Perry G, Smith MA, Bozner P (1998) Evidence of oxidative stress and in vivo neurotoxicity of beta-amyloid in a transgenic mouse model of Alzheimer's disease: a chronic oxidative paradigm for testing antioxidant therapies in vivo. Am J Pathol 152(4):871877

103. Heo HJ, Lee CY (2005) Strawberry and its anthocyanins reduce oxidative stress-induced apoptosis in PC12 cells. J Agric Food Chem 53(6):1984-1989

104. Ma T, Tan MS, Yu JT, Tan L (2014) Resveratrol as a therapeutic agent for Alzheimer's disease. Biomed Res Int 2014:350516. Published online 2014 Nov 26. https://doi.org/10.1155/2014/350516

105. Runyoro D, Ngassapa O, Vagionas K, Aligiannis N, Graikou K, Chinou I (2009) Chemical composition and antimicrobial activity of the essential oils of four Ocimum species growing in Tanzania. Planta Med 75. https://doi.org/10.1 055/s-0029-1234339

106. Paton A, Harley MR, Harley MM (1999) Ocimum: an overview of classification and relationships. In: Hiltunen R, Holm Y (eds) Basil: The Genus Ocimum. Harwood Academic Publishers, Amsterdam, pp 1-38

107. Paton A, Putievsky E (1996) Taxonomic problems and cytotaxonomic relationships between and within varieties of Ocimum basilicum and related species (Labiatae). Kew Bull 51:509-524

108. Inbaneson S, Sundaram R, Suganthi $P$ (2012) In vitro antiplasmodial effect of ethanolic extracts of traditional medicinal plant Ocimum species against Plasmodium falciparum. Asian Pac J Trop Med 5:103-106. https://doi.org/1 0.1016/S1995-7645(12)60004-2

109. Bihari GC, Manaswini B, Prabhat J, Kumar TS (2011a) Pharmacognostical and phytochemical investigation of various tulsi plants available in south eastern Odisha. Int J Res Pharmaceut Biomed Sci 2(2):605-610 2011 Vol.2 No.2 pp. 605-610 ref.14 http://www.jirpbsonline.com/files/RSO

110. Blank AF, Santa Rosa YR, de Carvalho Filho JLS, dos Santos CA, de Fátima ABM, dos Santos NE (2012) A diallel study of yield components and essential oil constituents in basil (Ocimum basilicum L.). Ind Crop Prod 38:93-98. https://doi.org/10.1016/j.indcrop.2012.01.015

111. Hiltunen R, Holm Y (1999) Bioactivity of basil. In: Hiltunen R, Holm Y (eds) Basil: The Genus Ocimum. Harwood Academic Publishers, The Netherlands, pp 113-135 R Hiltunen, Y Holm - Basil: the genus Ocimum 1999 - Basil: the genus Ocimum. - CAB Direct; https://www.cabdirect.org

112. Bilal A, Jahan N, Ahmed A, Bilal SN, Habib S, Hajra S (2012) Phytochemical and pharmacological studies on Ocimum basilicum Linn-A review. Int J Curr Res Rev 4:73-83

113. Sundarraju D, Anbu J, Ravichandran V, Senthil Kumar KL (2014) In vitro free radical scavenging potential of poly herbal extract. Int J Phytopharmacol $5(2): 71-75$

114. Chattopadhyay RR (1999) A comparative evaluation of some blood sugar lowering agents of plant origin. J Ethnopharmacol 67:367-372

115. Duke JA, Ayensu ES (1985) Medicinal plants of China. Reference Publications

116. Mohd-Zahid MH, Jalil J, Chan KM, Azmi N (2018) Neuroprotective effects of Ocimum basilicum extract against hydrogen peroxide-induced oxidative stress in SK-N-SH neuroblastoma cells. Sains Malaysiana 47(9):2129-2139. https://doi.org/10.17576/jsm-2018-4709-22

117. Pullaiah T (2006) Encyclopaedia of world medicinal plants. Daya books

118. Eftekhar N, Moghimi A, Nema MR, Saeideh S, Boskabady MH (2019) Immunomodulatory and anti-inflammatory effects of hydro-ethanolic extract of Ocimum basilicum leaves and its effect on lung pathological changes in an ovalbumin-induced rat model of asthma. BMC Complement Altern Med 19:349. https://doi.org/10.1186/s12906-019-2765-4

119. Adiguzel A, Gulluce M, Sengul M, Ogutcu H, Sahin F, Karaman (2005) Antimicrobial effects of Ocimum basilicum (Labiatae) extract. Turk J Biol 29: 155-160 https://journals.tubitak.gov.tr/biology/abstract.htm?id=7635

120. Akhtar MS, Munir M (1989) Evaluation of the gastric antiulcerogenic effects of Solanum nigrum, Brassica oleracea and Ocimum basilicum in rats. $J$ Ethnopharmacol 27(1-2):163-176

121. Dasgupta T, Rao AR, Pramod Y (2004) Chemomodulatory efficacy of Basil leaf (Ocimum basilicum) on drug metabolizing and antioxidant enzymes, and on carcinogen-induced skin and forestomach papillomagenesis. Phytomed Int J Phytother Phytopharmacol 11:139-151

122. Bihari CG, Manaswini B, Kumar JP, Kumar TS (2011) Pharmacognostical and phytochemical investigation of various tulsiplants available in south eastern odisha. Int J Res Pharmaceut Biomed Sci 2(2):60-63 International Journal of
Research in Pharmaceutical and Biomedical Sciences 2011 Vol.2 No.2 pp. 605-610 ref.14) http://www.jirpbsonline.com/files/RS0

123. Zeggwagh N, Thierry S, Eddouks M (2007) Anti-hyperglycaemic and hypolipidemic effects of Ocimum basilicum aqueous extract in diabetic rats. Am J Pharmacol Toxicol 2:123-129

124. Marzouk AM (2009) Hepatoprotective triterpenes from hairy root cultures of Ocimum basilicum L. Z Naturforsch C 64:201-209

125. Dashputre NL, Naikwade NS (2010) Preliminary immunomodulatory activity of aqueous and ethanolic leaves extracts of Ocimum basilicum Linn in mice. Int J Pharm Tech Res 2:1342-1349 International Journal of PharmTech Research 2010 Vol.2 No.2 pp.1342-1349 ref.26) http://sphinxsai.com/s_v2_ $\overline{\mathrm{n} 2 / \mathrm{PT} \_\mathrm{V} .2 \mathrm{No}}$

126. Shakeri F, Hosseini M, Ghorbani A (2019) Neuropharmacological effects of Ocimum basilicum and its constituents. Physiol Pharmacol 23:70-81 http://ppj. phypha.ir/article-1-1450-en.html (http://eprints.mums.ac.ir/id/eprint/28229

127. Tewari D, Pandey H, Sah A, Meena H, Aarti M (2012) Pharmacognostical and biochemical investigation of Ocimum kilimandscharicum plants available in western Himalayan region. Asian J Plant Sci Res 2:446-451 www.pelagia researchlibrary.com

128. Okoye FBC, Obonga WO, Onyegbule FA, Ndu OO, Ihekwereme CP (2014) Chemical composition and anti-inflammatory activity of essential oils from the leaves of Ocimum basilicum I. and Ocimum gratissimum L.(lamiaceae). Int J Pharm Sci Res 5(6):2174-2180. https://doi.org/10.13040/IJPSR.09758232.5(6).2174-80

129. Labra M, Miele M, Ledda B, Fabrizio Grassi F, Mazzei M, Sala F (2004) Morphological characterization, essential oil composition and DNA genotyping of Ocimum basilicum L. cultivars. Plant Sci 167:725-731

130. Telci I, Bayram E, Yilmaz G, Avci B (2006) Variability in essential oil composition of Turkish basils (Ocimun basilicum L.). Biochem Syst Ecol 34(6):489-497. https://doi.org/10.1016/j.bse.2006.01.009

131. Hanif MA, Al-Maskari MY, Al-Maskari A, Al-Shukaili A, Al-Maskari AY, Al-Sabah JN (2011) Essential oil composition, antimicrobial and antioxidant activities of unexplored Omani basil. J Med Plant Res 5:751-757 (Journal of Medicinal Plants Research Vol. 5(5), pp. 751-757, 4 March, 2011) Available online at http://www.academicjournals.org/JMPR

132. Kwee EM, Niemeyer ED (2011) Variations in phenolic composition and antioxidant properties among 15 basil (Ocimum basilicum L.) cultivars. Food Chem 128(4):1044-1050

133. Bhatt R, Neeraj M, Kumar P (2013) Phytochemical, pharmacological and pharmacokinetics effects of rosmarinic acid. J Pharma Sci Innov 2:28-34 https://doi.org/10.7897/2277-4572.02215

134. Rehman MU, Wali AF, Ahmad A, Shakeel S, Rasool S, Ali R, Rashid SM Madkhali H, Ganaie MA, Khan R (2019) Neuroprotective strategies for neurological disorders by natural products: an update. Curr Neuropharmacol 17(3):247-267

135. Wang F, Shing M, Huen Y, Tsang SY, Xue H (2004) Neuroactive flavonoids interacting with GABAA receptor complex. Curr Drug Targets CNS Neurol Disord 4(5):575-585

136. Luk KC, Stern L, Weigele M, O'Brien RA, Spirt N (1983) Isolation and identification of "diazepam-like" compounds from bovine urine. J Nat Prod 46(6):852-861

137. Häberlein H, Tschiersch KP, Boonen G, Hiller KO (1996) Chelidonium majus L.: components with in vitro affinity for the GABAA receptor. Positive cooperation of alkaloids. Planta Med 62(3):227-231

138. Leung WC, Zheng H, Huen M, Law SL, Xue H (2003) Anxiolyticlike action of orally administered dl-tetrahydropalmatine in elevated plus-maze. Prog Neuro-Psychopharmacol Biol Psychiatry 27(5):775-779

139. Liao JF, Wang HH, Chen MC, Chen CC, Chen CF (1998) Benzodiazepine binding site-interactive flavones from Scutellaria baicalensis root. Planta Med 64(6):571-572

140. Hui KM, Wang XH, Xue H (2000) Interaction of flavones from the roots of Scutellaria baicalensis with the benzodiazepine site. Planta Med 66(1):91-93

141. Spencer JP (2009) The impact of flavonoids on memory: physiologicaland molecular considerations. Chem Soc Rev 38(4):1152-1161

142. Lin RD, Hou WC, Yen KY, Lee MH (2003) Inhibition of monoamineoxidase B (MAO-B) by Chinese herbal medicines. Phytomed. 10(8):650-656. https://doi. org/10.1078/0944-7113-00324

143. Huang C, Li WG, Zhang X, Xu TL, Wu D, Li Y (2012) Alpha-asarone from Acorus gramineus alleviates epilepsy by modulating A-Type GABA receptors. Neuropharmacol 65C:1-11. https://doi.org/10.1016/j.neuropharm.2 012.09 .001 
144. Diniz TC, Silva JC, de Lima-Saraiva SRG, de Almeida Ribeiro FPR, Pacheco AGM, de Freitas RM, Quintans-Júnior LJ, de Souza JSQ, Mendes RL, da Silva Almeida JRG $(2015,2015)$ The role of flavonoids on oxidative stress in epilepsy. Oxidative Med Cell Longev 171756. Published online 2015 Jan 11. https://doi.org/10.1155/2015/171756

145. Daniëlle C, Adriana O, Gert S, Zhang Y, Annelii N, Kenn F, Vasiliki E, Ola S, Youngju K, Wim B, Wim LP, de Witte P (2017) Methylated flavonoids as antiseizure agents: Naringenin 4,7-dimethyl ether attenuates epileptic seizures in zebrafish and mouse models. Neurochem Int 112. https://doi.org/10.101 6/j.neuint.2017.11.011

146. Phippen WB, Simon JE (1998) Anthocyanins in Basil (Ocimum basilicum L.). J Agric Food Chem 46(5):1734-1738

147. Uma DP, Ganasoundri A, Vindra B, Srinivasan KK, Unnikrishnan MK (2000) Radiation protection by the ocimum flavonoids orientin and vicenin: mechanisms of action. Radiat Res 154:455-460

148. Baliga MS, Jimmy R, Thilakch KR, Sunitha V, Bhat NR, Saldanha E, Rao S, Rao P, Arora R, Palatty PL (2013) Ocimum sanctum L (Holy Basil or Tulsi) and its phytochemicals in the prevention and treatment of cancer. Nutr Cancer 65(Suppl 1):26-35

149. Kumar S, Bouic PJ, Rosenkranz B (2020) In vitro assessment of the interaction potential of Ocimum basilicum (L.) extracts on CYP2B6, 3A4, and rifampicin metabolism. Front Pharmacol 11:517

150. Misra M (1998) Photosynthetic pigment content and essential oil yield of Ocimum basilicul L. during different stages of growth in the field. In: Garab $\mathrm{G}$ (ed) photosynthesis: mechanisms and effects. Kluwer, The Netherlands, pp 3825-3828

151. Misra M, Sahoo S, Devta BK (1998) Micropropagation of sweet basil (Ocimum basilicum L.). National Seminar on Aromatic Plants of India: Exploration and utilisation, Bhubaneswar, p 17

152. Al-Maskria AY, Hanifa MA, Al-Maskarib MY, Abrahama AS, Al-sabahic JN, AlMantheria O (2011) Essential oil from Ocimum basilicum (Omani Basil): a desert crop. Nat Prod Commun 6(10):1487-1490. https://doi.org/10.1177/1 $934578 \times 1100601020$

153. Joshi RK (2014) Chemical composition and antimicrobial activity of the essential oil of Ocimum basilicum L. (sweet basil) from Western Ghats of North West Karnataka, India. Anc Sci Life 33(3):151-156. https://doi.org/10.41 03/0257-7941.144618

154. Amal MA, Ladwani SM, Abdel Hameed ES (2017) Chemical composition of Ocimum basilicum L. essential oil from different regions in the Kingdom of Saudi Arabia by using Gas chromatography mass spectrometer. J Med Plants Stud 6(1):14-19 www.plantsjournal.com

155. Poonkodi K (2016) Chemical composition of essential oil of Ocimum basilicuml. (BASIL) and its biological activities-an overview. J Crit Rev 3(3): 56-62 http://creativecommons.org/licenses/by/4.0/

156. Bhaskaruni R, Rao R, Sushil K, Kothari DK, Rajput RP, Patel MP, Darokar (2019) Chemical and biological diversity in fourteen selections of four Ocimum species. Nat Prod Commun 6(11):1705-1710. https://doi.org/10.1177/1934 $578 \times 1100601134$

157. Koutroumanidis M, Arzimanoglou A, Caraballo R, Goyal S, Kaminska A, Laoprasert P, Oguni H, Rubboli G, Tatum W, Thomas P, Trinka E, Vignatelli L, Moshé SL (2017) The role of EEG in the diagnosis and classification of the epilepsy syndromes: a tool for clinical practice by the ILAE Neurophysiology Task Force (Part 2). Epileptic Dis 19:385-437

158. Okoli CO, Ezike AC, Agwagah OC, Akah PA (2010) Anticonvulsant and anxiolytic evaluation of leaf extracts of Ocimum gratissimum, a culinary herb. Pharm Res 2(1):36-40. https://doi.org/10.4103/0974-8490.60580

159. Bahr TA, Rodriguez D, Beaumont C, Allred K (2019) The effects of various essential oils on epilepsy and acute seizure: a systematic review. Evid Based Complement Alternat Med 2019:6216745

160. Annafi OS, Umukoro S, Eduviere AT (2014) Evaluation of the anticonvulsant and anxiolytic potentials of methyl jasmonate in mice. Sci Pharm 82(3):643654

161. Chen X, Guo C, Kong J (2012) Oxidative stress in neurodegenerative diseases.Neural. Regen Res 7(5):376-385

162. Petersen M, Simmonds MS (2003) Rosmarinic acid. Phytochem 62(2):121-125

163. Fadel O, El K, Morandat S (2011) The natural antioxidant rosmarinic acid spontaneously penetrates membranes to inhibit lipid peroxidation in situ. Biochim Biophys Acta 1808(12):2973-2980. https://doi.org/10.1016/j.bba mem.2011.08.011

164. De Oliveira NC, Sarmento MS, Nunes EA, Porto CM, Rosa DP, Bona SR, Rodrigues G, Marroni NP, Pereire P, Picada JN, Ferraz AB, Thiesen F, Da Silva
$J$ (2012) Rosmarinic acid as a protective agent against genotoxicity of ethanol in mice. Food Chem Toxicol 50(5):1208-1214

165. Wang Q, Yu S, Simonyi A, Sun GY, Sun AY (2005) Kainic acid-mediated excitotoxicity as a model for neurodegeneration. Mol Neurobiol 31(1-3):316

166. Khamse S, Sadr SS, Roghani M, Hasanzadeh G, Mohammadian M (2015) Rosmarinic acid exerts a neuroprotective effect in the kainate rat model of temporal lobe epilepsy: Underlying mechanisms. Pharm Biol 53(12):18181825. https://doi.org/10.3109/13880209.2015.1010738

167. Fonteles AA, de Souza CM, de Sauza Neves JC, Menezes AP, Santos do Carmo MR, Fernandes FD, de Araujo PR, de Andrade GM (2015) Rosmarinic acid prevents against memory deficits in ischemic mice. Behav Brain Res 297:91-103

168. Ghaffari $H$, Venkataramana M, Jalali Ghassam B, Chandra Nayaka S, Nataraju A, Geetha NP, Prakash HS (2014) Rosmarinic acid mediated neuroprotective effects against $\mathrm{H} 2 \mathrm{O} 2$-induced neuronal cell damage in N2A cells. Life Sci 113(1-2):7-13. https://doi.org/10.1016/j.lfs.2014.07.010

169. Nakazawa T, Ohsawa K (1998) Metabolism of rosmarinic acid in rats. J Nat Prod 61(8):993-996

170. Baba S, Osakabe N, Natsume M, Terao J (2004) Orally administered rosmarinic acid is present as the conjugated and/or methylated forms in plasma, and is degraded and metabolized to conjugated forms of caffeic acid, ferulic acid and $m$-coumaric acid. Life Sci 75(2):165-178

171. Yang JH, Zhang L, Li JS, Chen LH, Zheng Q, Chen T, Chen ZP, Fu TM, Di LQ (2015) Enhanced oral bioavailability and prophylactic effects on oxidative stress and hepatic damage of an oil solution containing a rosmarinic acidphospholipid complex. J Funct Foods 19:63-73

172. Kim IH, Yan BC, Park JH, Yeu GH, Yim Y, Ahn JH, Lee JC, Hwang IK, Cho JH, Kim YM, Lee YL, Park JH, Won MH (2013) Neuroprotection of a novel synthetic caffeic acid-syringic acid hybrid compound against experimentally induced transient cerebral ischemic damage. Planta Med 79(5):313-321

173. Jeong $\mathrm{CH}$, Jeong HR, Choi GN, Kim DO, Lee U, Heo HJ (2011) Neuroprotective and anti-oxidant effects of caffeic acid isolated from Erigeron annuus leaf. Chin Med 6:25. https://doi.org/10.1186/1749-8546-6-25

174. Anwar J, Spanevello RM, Thomé G, Stefanello N, Schmatz R, Gutierres J, Vieira J, Baldissarelli J, Carvalho FB, da Rosa MM, Rubin MA, Fiorenza A, Morsch VM, Schetinger MR (2012) Effects of caffeic acid on behavioral parameters and on the activity of acetylcholinesterase in different tissues from adult rats. Pharmacol Biochem Behav 103(2):386-394. https://doi.org/1 0.1016/j.pbb.2012.09.006

175. Gülçin I (2011) Antioxidant activity of eugenol: a structure-activity relationship study. J Med Food 14(9):975-985

176. Nam H, Kim MM (2013) Eugenol with antioxidant activity inhibits MMP-9 related to metastasis in human fibrosarcoma cells. Food Chem Toxicol 55: 106-112

177. Mahapatra SK, Roy S (2014) Phytopharmacological approach of free radical scavenging and anti-oxidative potential of eugenol and Ocimum gratissimum Linn. Asian Pac J Trop Med 7(S1):S391-S397

178. Prasad SN, Muralidhara (2012) Neuroprotective efficacy of eugenol and isoeugenol in acrylamide-induced neuropathy in rats: Behavioral and biochemical evidence. Neurochem Res 38(2):330-345. https://doi.org/10.1 007/s11064-012-0924-9

179. Won MH, Lee JC, Kim YH, Song DK, Suh HW, Oh YS, Kim JH, Shin TK, Lee YJ, Wie MB (1998) Postischemic hypothermia induced by eugenol protects hippocampal neurons from global ischemia in gerbils. Neurosci Lett 254(2): 101-104

180. Wei H, Fiskum G, Rosenthal RE, Robert E, Perry AU, David C (1997) Global cerebral ischemia and reperfusion alters NMDA receptor binding in canine brain. Mol Chem Neuropathol 30(1-2):25-39. https://doi.org/10.1007/BF0281 5148

181. Bora KS, Arora S, Shri R (2011) Role of Ocimum basilicum L. in prevention of ischemia and reperfusion-induced cerebral damage, and motor dysfunctions in mice brain. J. Ethnopharmacol. 137(3):1360-1365

182. Singh V, Kahol A, Singh IP, Saraf I, Shri R (2016) Evaluation of anti-amnesic effect of extracts of selected Ocimum species using in-vitro and in-vivo models. J Ethnopharmacol 193:490-499. https://doi.org/10.1016/j.jep.2016.1 0.026

\section{Publisher's Note}

Springer Nature remains neutral with regard to jurisdictional claims in published maps and institutional affiliations. 